\title{
Globalization of English language: a blessing or curse on Kurdish language
}

\author{
Khoshy Anwar Hassan ${ }^{1}$, Shokhan Anwar Hassan² \\ ${ }^{1}$ Department of English Language, College of Education- University of Garmian \\ ${ }^{2}$ Kalar Computer Institute. Ministry of Education-General Directorate of Institutes and Trainings
}

\section{Article Info}

Received: October, 2019

Revised: November, 2019

Accepted: December, 2019

\section{Keywords}

globalization, English language, Kurdish language, reviving language, minority language.

Corresponding Author khoshy.anwar@garmian.edu.krd

\begin{abstract}
The language we use, like many other things such as sun shine, water, air, rain, sound, food ...etc is in a rapid change. Different studies and surveys are found about the number of languages that have disappeared in the last 500 years. At an alarming rate, many languages are dying and many others are reviving all over the world, as Crystal (2000: 1) defines language death as "a language dies when nobody speaks it any more" and this idea is close to Campbell's (1994) view point when he states that "The loss of a language due to gradual shift to the dominant language in language contact situations". Kurdish language is an example of a minority language as being surrounded by Persian, Turkish, Arabic and some other majority languages such as English. Kurdish language is not apart from many other languages that are in a critical situation whether to revive or die. As the world becomes more connected, language diversity is falling at an unprecedented rate. Globalization is about human contact. Indeed, the continental, and later global spread of certain languages is the clearest long-term evidence of what global contacts have been achieved. Beside its advantage for some languages to help them becoming the dominant language, yet it helps in polluting the minority languages. The present study is a descriptive analytic study. It aims at knowing whether English language, which is a globalized language, is a curse or blessing to the educated Kurdish language speakers in the age of 15-30 at Kurdistan regional government (KRG)/Garmian province. This is by preparing the descriptive and inferential information, the descriptive data including the age, gender and sentences with choosing a Kurdish or English words. The data showed that there is a rapid increase of using and preferring English words in the daily conversations instead of the Kurdish words. The study found that Kurdish speakers at the age of 15-20 years old are using English words in a higher rate than the ages of 21-25 and 26-30, and higher in 21-25 than 26-30 years old.
\end{abstract}

\section{Introduction}

Globalization is a prompting power in all places in the world. It alerts us that in addition to the prescriptive slogan 'think globally, act locally', Hogan (1996) believes that, there must be an extra critical observation that we also 'think locally, act globally'. English language is considered as a globalized language. Since the number of second language speakers of English language are more than those whom it is the mother tongue. Gradually, communicating with English language needs no first langue speakers at all (Jenkins 2000:1). Another point that confirms the idea of globalization of English language is that it is obviously recognized in almost every country. Moreover, both Graddol (1999) and Jenkins (2000) believe that "the 
increasing popularity of English as a language of communication among the non-native speakers will certainly give them a huge chance to determine the future of English, and to some extent, a prominent "norm-providing" status as well".

Another view point confirming the idea of English as a global language is shown by Crystal (1997), in which English is prominently known in almost every country around the world. The role of English language as a globalized language specifically can be achieved only by making English an official language used in government offices, law courts, and in the media and education systems of the country. For that reason, sometimes English is called a second, an additional, or an auxiliary language. In addition to using English as the official language, it is also preferred in foreign language teaching even though it is not the second language in the country.

\section{English language: a curse or blessing on} Kurdish language

After 2003, when Iraq was invaded by a combined force of troops from the United States, the United Kingdom, Australia and Poland, English language began to dominate Iraq and gradually it became one of the important skills in almost every aspects of life. Iraq-Kurdistan is a reign located in the north of Iraq and it is considered as the most secured part of Iraq. Most of the international NGOs, diplomats, Politian and military points are located in this region. For that reason, the need for learning English language has increased. Many scholars with different perspectives start to argue about the existence of English language whether it is a curse or blessing for the Kurdistan region. Some maintain that English language is a curse to Kurdish language whereas some others consider that a force of blessing for the Kurdish language.

\section{Blessing on Kurdish language}

The growth for the need of English language in Kurdistan region can be traced to different points such as: the nature of the Kurdish society (people speaking different languages such as; Kurdish, Turkoman, Assyrian and Armenian). Besides the nature of the society, Kurdistan region is going through a very fast progress of economic status since Kurdistan region is depending on importing more than exporting. Since it is considered as the most secured part of Iraq, different NGOs and companies are located in Kurdistan region. Just like many other progressing countries, after 2003, access to internet and social media became faster and more demandable. Thus, in order for the Kurdish people to couch up with the mentioned ideas as fast and easy way as possible and to avoid language barrier, they start to borrow words from English language. According to Hoffer (2002:1) Borrowing is "the process of importing linguistic items from one linguistic system into another, a process that occurs any time two cultures are in contact over a period of time". With the diverse of language, the only language that is intelligible to many is English, since English is a globalized language. Based on this fact, using and interfering English words into the speech is making communication easier and faster for the Kurdish language speakers.

To sum, it is very obvious that the situation that Kurdistan region is going through needs Kurdish language to borrow form English language. Because of the globalization of English language, the demands for using English terms is increasing. Besides, Kurdish people prefer depending on English words so as to be used instead of the terms and vocabularies that do not exist in Kurdish language. In addition, it is clear that borrowing is easier than inventing a new term. In order to communicate easier, Kurdish people know how to use borrowed words while speaking in Kurdish language. 


\section{Curse on Kurdish language}

The promotion of using English words is nurtured by the prestige and rich people attached to it and its speakers. In Kurdistan region, users of English words or English speakers are regarded as educated and enlightened in the society. However the equivalent words are found in Kurdish language, in one way or another people are trying to use English words and learn English either non-formally or formally. People are doing this so as to have a sense of belonging, in addition, some others prefer code-mixing or code-switching instead of trying to speak fluently in the their mother language. According to Poplack (2001) code-switching refers to "the mixing, by bilinguals (or multilinguals), of two or more languages in discourse, often with no change of interlocutor or topic." However, some people do not understand English, yet they try to speak English like language since English is the target language. Thus, they are careless about the grammatical construction, usually they track the forms of native language. These are all considered as a way of spreading English language.

As a result of that, it is argued that the spread of English language is considered as a curse to the mother language (Kurdish language). In other words, accepting and using English instead of Kurdish words may end up by damaging the later, since it makes the value of Kurdish language to be less by its speakers. The argument is based on the fact that Kurdish language is practical mean of protecting its culture and values.

\section{Methodology}

The present study is a descriptive analytic study. The purpose of the study is to examine whether the globalization of English language is a curse or blessing for the educated Kurdish speakers. Students from ages 15-30 years old were included and participated in this research. The reason behind choosing such age is due to the quick changes that happened to KRG after the invasion of Iraq in 2003 which was for ending up the authority of Saddam Hussain. Moreover, this age is considered as the future of a society. The study covered 90 students in Garmian province consisting of 45 males and 45 females. According to gender and age, the students were divided into three groups 15-20 (15males, and 15females), 21-25 years old (15males, and 15females), and 26-30 years old (15males, 15females).

In collecting data, survey questions were used. The questioner was translated into Kurdish language by experts in English language inside KRG-Iraq and then translated back into English language by experts in the field of English linguistics at Garmian University. Since the samples are native Kurdish speakers, the questioner were in Kurdish language. The students were given free choice to be part of this study or not. In the questioner, participants were giving sentences with a missing word and then choosing between two words, one English and the other Kurdish, to be used in the place of the missing word. It took 25-30 minutes for the participants to fill out the questionnaire.

\section{Results}

1- As it is reported in chart number 1 , in which the data shows that $50 \%$ of the participants were females and $50 \%$ were males.

2- Chart (1) number of male and female students according to age group.

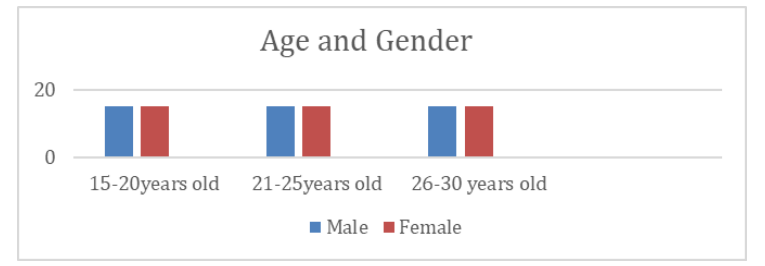

Chart (1) number of male and female students according to age group

According to the obtained results, there is similarity between genders and ages in 
answering items 1, and 11. Consequently, in question number 1, all the three age groups and both genders use English words instead of the Kurdish words. In question number 11, all female students in all ages are using English words, while just like female students, all male students are using English words except for the age 21-25 in which they use the Kurdish word. The result also show that using English words by the youngest group (15-20 years old) is higher than the other age groups and whenever the age goes higher, the use of English words decreases. From this result, one may conclude that both genders in the age of 15-20yaears old, have the same desire toward using English more than the Kurdish words even though the Kurdish equivalent of the English words are found. In addition to that, they score the highest rate of using English instead of the Kurdish equivalent words compared to the other age groups.

\section{Discussion}

In shedding light on the possible reasons behind such finding, the importance and use of English language has remarkably increased among young native educated Kurdish speakers in Kurdistan regional government. This is as a result of the socio-economical and educational reasons that have affected every aspect of people's lives. Socioeconomic is "the field of study that examines social and economic factors to better understand how the combination of both influences something" (Business Dictionary, 2018). It can be said that in KRG, the most common and obvious socioeconomic factors are; fast economic transformation, deficiency of economic opportunities, patterns of work, migrant labor. After 2003, KRG's importing process from other countries has increased in a very fast way, this is because KRG lacks factories and domestic product, thus people started to use English equivalent of Kurdish words since English language is a globalized language. Besides that, as a result of the fast economic transportation, patterns of work has changed from the routing style of work (which is working in the government sectors) into a new style of work, which is working for private sectors and accepting in a position according to a standard way which is $\mathrm{CV}$ and interview. Job demands in the private sectors nowadays are all asking for knowing English language as a priority and then knowing Kurdish language as a minor demand. They try to use English language in their work and then reflecting in their way of expression, way of thinking and their daily life. Educational system is considered as another reason behind such finding. Due to the different qualified private schools and centers that have been established after 2003 in almost all cities, parents prefer their children to study in such private schools rather than the public ones. Since the quality of education in the public schools is significantly less than in the private schools.

Since Kurdish language is the minority language in Iraq, English is believed to exchange and weaken native Kurdish language and pushing it toward having no secure cultural legacy that the Kurdish society earns. Consequently, this leads to speeding up the death of Kurdish language as a minority language in Iraq since the new Kurdish generation acquire English as their mother language to express themselves while finding it difficult to use their original mother language (Kurdish language). Besides, in the north part of Iraq, people who are not really fluent in English choose Pidgin English as their mother tongue, and ages after ages coming after them acquire it.

\section{Conclusions}

It is concluded that the globalization of English language is a curse on Kurdish language. This is due to the reason that the young native educated Kurdish speakers, whom are considered as the heart and mind of society and the basic factor for a language to survive, prefer using English 
words instead of their mother language. This result is supported by a questioner given to Kurdish students in both genders aged 15-30. Students were divided into three age groups; $15-$ 20, 21-25, and 26-30 years old. After a detailed analyzation of the results, the study indicated that $83.8 \%$ of male students and $74.2 \%$ of female students in the age group 15-20 significantly prefer using English words instead of the Kurdish words. The same statement is applied to the age group 21-25 in which $61.3 \%$ of male students and $67.7 \%$ of female students are using English words. As for the third age group which is 26-30, this result decreases to $35.5 \%$ of male students and $45.2 \%$ of female students in using English words.

To sum, the limit of the study is indicated to the educated speakers at the ages of 15-30 in Gramian province at KRG. For that reason, to have a more generalized result, researchers suggest having similar study for students under 15 years old. In the end, researchers thank students in Garmian University and Kalar computer institution, translators in both English and Kurdish languages for their kind assistance.

\section{References}

1. Campbell, Lyle. (1994). Language death. Asher \& Simpson 1994, vol.4. 1960-1968.

2. Crystal, D. (1997). English as a Global Language. Cambridge: Cambridge University, Press.

3. ---------- (2000). Language Death. Cambridge, United Kingdom: Cambridge University Press.

4. Graddol, D. (1997). The Future of English. London: The British Council.

5. Jenkins, J. (2000). The Phonology of English as an International Language. Oxford: Oxford University Press

6. Hoffer, L. Bates. (2002). Language Borrowing-Overview 1 Language Borrowing and Language Diffusion. Intercultural
Communication Studies XI: 4. San Antonio, TX, United States: Trinity University Press.

7. Hogan, T. (1996). Globalization: Experiences and explanations. In A. Kellehear (Ed.), Social Self, Global Culture. Oxford: Oxford University Press.

8. Poplack, Shana. (2001). code-switching (linguistics). In Smelser,Niel \& Baltes,Paul (eds.), international encyclopedia of the social and behavioral sciences. Elsevier Science Ltd.2062-2065.

9. Socioeconomic. BusinessDictionary.com. WebFinance, Inc. September 24, 2018 $<$ http//www.businessdictionary.com/definiti on/socioeconomic.html>. (Retrieved in 12 October 2019). 
Table (1) Common borrowed words from English that has no equivalent word in Kurdish language

\begin{tabular}{|c|c|}
\hline English Words & Kurdish Words \\
\hline Staff & ستاف \\
\hline Group & كروب" \\
\hline Piano & يِيانو \\
\hline Portal & يُوْرَتال \\
\hline Computer & كوّ ميِيو تشر \\
\hline Mobile & موّبايل \\
\hline Television & تهلهففزيونَ \\
\hline Power bank & ياور بانك \\
\hline Satellite & سهنتهلايت \\
\hline Drill & دريّل \\
\hline Tape & تينّب \\
\hline Wire & وايهر \\
\hline Radar & رادار \\
\hline Tire & تايه \\
\hline Sponge & ئيسبانهن \\
\hline Cacao & كاكاو \\
\hline Drama & در اما \\
\hline Hack & هاك \\
\hline plug & 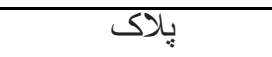 \\
\hline Cartoon & كارتوّن \\
\hline goal & كُول \\
\hline Hand break & هاندبريّك \\
\hline Pump & يامِّ" \\
\hline card & كارت \\
\hline Motor & ماتوّر \\
\hline Folklore & فُوْلكؤر \\
\hline Gear & كَيْر \\
\hline System & سيستاهم \\
\hline Cinema & سيناهما \\
\hline camera & كاميّرا \\
\hline $\log 0$ & لولوكُّ \\
\hline Video clip & قَيديوّ كليبٍ \\
\hline wheel & ويل \\
\hline fax & فاكس \\
\hline scan & سكان \\
\hline Flash camera & فلاش كاميّر \\
\hline
\end{tabular}


Table (2) common borrowed words from English with their equivalent words in Kurdish language.

\begin{tabular}{|c|c|}
\hline English Words & Kurdish Words \\
\hline comment & وته \\
\hline dialogue & كفتوكوّ \\
\hline principle & بناdما \\
\hline bye & خو ات لهكهل \\
\hline hello & سآو \\
\hline ideology & بيردوزَى \\
\hline center & ناو نند \\
\hline positive & ئهُ رِينَى \\
\hline text & دهق \\
\hline modern & هاوجهار خ \\
\hline control & دهست بـسـاهركرتن \\
\hline toilet & ساهرئاو ، نئاو دهست \\
\hline memory & بيركاه، يادكاه \\
\hline market & دوكان -باز ار \\
\hline light & روناكى \\
\hline photography & ويّنهكرتن \\
\hline save & يار استن \\
\hline message & عبّالان \\
\hline doctor & يزيشَك \\
\hline media & دززكاى ري اكهيائدن \\
\hline Canton & هانَّم \\
\hline civil & شَارستانى \\
\hline freezer & باهفركر \\
\hline active & جالاك \\
\hline debate & كَفتوكوّ \\
\hline genocide & كوّمسل كوزَى \\
\hline actor & نمايشـكار \\
\hline title & ناونيشان \\
\hline program & بـرنامه \\
\hline frequency & للهرهلير \\
\hline bicycle & لوجهار خه \\
\hline list & ريزبهند \\
\hline ok & باش-بالَّي \\
\hline stress & فنشارى دهرونى \\
\hline
\end{tabular}


Table (3) the descriptive data of the sample group

\begin{tabular}{|c|c|c|}
\hline Gender & Frequency & Percent \\
\hline Male & 45 & $\% 50$ \\
\hline Female & 45 & $\% 50$ \\
\hline Total & 90 & $\% 100.0$ \\
\hline
\end{tabular}

Table (4) Data of item by item analys is

\begin{tabular}{|c|c|c|c|c|c|c|c|c|c|c|c|c|}
\hline \multirow{3}{*}{ Questions } & \multicolumn{6}{|c|}{ Male } & \multicolumn{6}{|c|}{ Female } \\
\hline & \multicolumn{2}{|c|}{$15-20$ years old } & \multicolumn{2}{|c|}{ 21-25years old } & \multicolumn{2}{|c|}{ 26-30years old } & \multicolumn{2}{|c|}{$15-20$ years old } & \multicolumn{2}{|c|}{ 21-25years old } & \multicolumn{2}{|c|}{ 26-30years old } \\
\hline & English & Kurdish & English & \begin{tabular}{|l|} 
Kurdis \\
\end{tabular} & English & Kurdish & English & Kurdish & English & Kurdis & English & Kurdish \\
\hline$\overline{\mathrm{O} 1}$ & 1 & 0 & 1 & 0 & 1 & 0 & 1 & 0 & 1 & 0 & 1 & 0 \\
\hline Q2 & 0 & 1 & 0 & 1 & 0 & 1 & 0 & 1 & 1 & 0 & 0 & 1 \\
\hline Q3 & 1 & 0 & 1 & 0 & 0 & 1 & 0 & 1 & 1 & 0 & 1 & 0 \\
\hline Q4 & 1 & 0 & 0 & 1 & 0 & 1 & 1 & 0 & 0 & 1 & 0 & 1 \\
\hline Q5 & 1 & 0 & 0 & 1 & 0 & 1 & 1 & 0 & 0 & 1 & 0 & 1 \\
\hline$\overline{\mathrm{O} 6}$ & 1 & 0 & 1 & 0 & 0 & 1 & 1 & 0 & 1 & 0 & 0 & 1 \\
\hline Q7 & 1 & 0 & 1 & 0 & 1 & 0 & 1 & 0 & 1 & 0 & 1 & 0 \\
\hline Q8 & 0 & 1 & 0 & 1 & 0 & 1 & 0 & 1 & 0 & 1 & 0 & 1 \\
\hline Q9 & 1 & 0 & 1 & 0 & 1 & 0 & 1 & O & 1 & 0 & 1 & 0 \\
\hline Q10 & 1 & 0 & 1 & 0 & 1 & 0 & 1 & 0 & 1 & 0 & 1 & 0 \\
\hline Q11 & 1 & 0 & 0 & 1 & 1 & 0 & 1 & 0 & 1 & 0 & 1 & 0 \\
\hline Q12 & 1 & 0 & 0 & 1 & $\bar{O}$ & 1 & 0 & 1 & 1 & 0 & 0 & 1 \\
\hline O13 & 0 & 1 & 0 & 1 & 0 & 1 & 0 & 1 & 0 & 1 & 0 & 1 \\
\hline Q14 & 1 & 0 & 1 & 0 & 0 & 1 & 1 & 0 & 1 & 0 & 0 & 1 \\
\hline Q15 & 1 & 0 & 1 & 0 & 0 & 1 & 1 & 0 & 1 & 0 & 0 & 1 \\
\hline O16 & 1 & 0 & 0 & 1 & 0 & 1 & 0 & 1 & 0 & 1 & 0 & 1 \\
\hline Q17 & 1 & 0 & 0 & 1 & 0 & 1 & 1 & 0 & 1 & 0 & 0 & 1 \\
\hline Q18 & 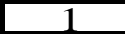 & 0 & 1 & 0 & 1 & 0 & 1 & 0 & 1 & 0 & 1 & 0 \\
\hline O19 & 1 & 0 & 1 & 0 & 1 & 0 & 1 & 0 & 1 & 0 & 1 & 0 \\
\hline 020 & 1 & 0 & 1 & 0 & 1 & 0 & 1 & 0 & 1 & 0 & 1 & 0 \\
\hline $\mathrm{Q} 21$ & 0 & 1 & 0 & 1 & 0 & 1 & 0 & 1 & 0 & 1 & 0 & 1 \\
\hline $\mathrm{Q} 22$ & 0 & 1 & 1 & 0 & 1 & 0 & 1 & 0 & 0 & 1 & 1 & 0 \\
\hline $\mathrm{Q} 23$ & 1 & 0 & 7 & 0 & 0 & 1 & 1 & 0 & 1 & $\overline{0}$ & 0 & 1 \\
\hline Q24 & 1 & 0 & 0 & 1 & 0 & 1 & 1 & 0 & 0 & 1 & 0 & 1 \\
\hline Q25 & 1 & 0 & 1 & 0 & 0 & 1 & 1 & 0 & 1 & 0 & 1 & 0 \\
\hline $\mathrm{O} 26$ & 1 & 0 & 1 & 0 & 1 & 0 & 1 & 0 & 0 & 1 & 1 & 0 \\
\hline Q27 & 1 & 0 & 1 & 0 & 0 & 1 & 1 & 0 & 1 & 0 & 0 & 1 \\
\hline $\mathrm{Q} 28$ & 1 & 0 & 0 & 1 & 0 & 1 & 0 & 1 & 1 & 0 & 1 & 0 \\
\hline Q29 & 1 & 0 & 1 & 0 & 0 & 1 & 1 & 0 & 1 & 0 & 0 & 1 \\
\hline 030 & 1 & 0 & 1 & 0 & 0 & 1 & 1 & 0 & 0 & 1 & 0 & 1 \\
\hline Q31 & 1 & 0 & 1 & 0 & 1 & 0 & 1 & 0 & 1 & 0 & 1 & 0 \\
\hline $\begin{array}{l}\text { TO TAL } \\
\end{array}$ & 26 & 5 & 19 & 12 & 11 & 20 & 23 & 8 & 21 & 10 & 14 & 17 \\
\hline
\end{tabular}

